\title{
The Enthalpies of Formation of $\mathrm{BeO}(\mathrm{c})$ and $\mathrm{BeF}_{2}(\mathrm{c})$
}

\author{
Vivian B. Parker \\ Institute for Materials Research, National Bureau of Standards, Washington, D.C. 20234
}

(November 9, 1972)

\begin{abstract}
Two of the key compounds in the evaluation and synthesis of a consistent set of thermodynamic values for the $\mathrm{Be}$ compounds are $\mathrm{BeO}(\mathrm{c})$ and $\mathrm{BeF}_{2}(\mathrm{c})$. The available measurements on the enthalpies of formation of these two compounds are presented with a detailed outline of the approach used to select the "best" values, $\Delta H f_{298.15 \mathrm{~K}}^{\circ}[\mathrm{BeO}(\mathrm{c})]=-145.7 \pm 0.6 \mathrm{kcal} \cdot \mathrm{mol}^{-1}\left(-609.6 \pm 2.5 \mathrm{~kJ} \cdot \mathrm{mol}^{-1}\right)$ and $\Delta H f_{298.15 \mathrm{~K}}^{\circ}\left[\mathrm{BeF}_{2}(\mathrm{c}\right.$, quartz $\left.)\right]=-245.4 \pm 0.8 \mathrm{kcal} \cdot \mathrm{mol}^{-1}\left(-1026.8 \pm 3.3 \mathrm{~kJ} \cdot \mathrm{mol}^{-1}\right)$.
\end{abstract}

Key words: $\mathrm{BeF}_{2}(\mathrm{c}) ; \mathrm{BeO}(\mathrm{c})$; beryllium fluoride; beryllium oxide; enthalpies of formation; $\Delta H f_{298.15 \mathrm{~K}}^{\circ}$ $\left[\mathrm{BeF}_{2}(\mathrm{c})\right] ; \Delta H f_{298.15 \mathrm{~K}}^{\circ}[\mathrm{BeO}(\mathrm{c})] ;$ thermochemistry.

\section{Introduction}

Two of the key compounds in the evaluation and synthesis of a consistent set of thermodynamic values for the $\mathrm{Be}$ compounds are $\mathrm{BeO}(\mathrm{c})$ and $\mathrm{BeF}_{2}(\mathrm{c})$.

One approach used in the preparation of compilations of thermochemical data is to start with a compound for which $\Delta H f^{\circ}$ (or $\Delta G f^{\circ}$ ) is definitive and independent of $\Delta H f^{\circ}$ of any other compound of that element and preferably involves a minimum of auxiliary $\Delta H f^{\circ} \mathrm{s}$, and to build from the selected value for this compound. An example of this is the direct oxidation of the metal to the oxide, e.g., $\mathrm{BeO}(\mathrm{c})$, or the halogenation of the metal to the halide, e.g., $\mathrm{BeF}_{2}$ (amorp), or a set of reactions that can be combined in such a way that only one $\Delta H f^{\circ}$ is unknown, e.g., $\mathrm{Be}(\mathrm{c})+2 \mathrm{HF}(\mathrm{aq}) \rightarrow$ $\mathrm{H}_{2}(\mathrm{~g})+\mathrm{BeF}_{2}(\mathrm{aq})$ and $\mathrm{BeO}(\mathrm{c})+2 \mathrm{HF}(\mathrm{aq}) \rightarrow \mathrm{BeF}_{2}(\mathrm{aq})+$ $\mathrm{H}_{2} \mathrm{O}$ (liq) so that by difference we can write the possible reaction, $\mathrm{Be}(\mathrm{c})+\mathrm{H}_{2} \mathrm{O}(\mathrm{liq}) \rightarrow \mathrm{BeO}(\mathrm{c})+\mathrm{H}_{2}(\mathrm{~g})$; similarly $\mathrm{Be}_{3} \mathrm{~N}_{2}(\mathrm{c})+3 / 20_{2}(\mathrm{~g}) \rightarrow 3 \mathrm{BeO}(\mathrm{c})+\mathrm{N}_{2}(\mathrm{~g})$ and $3 \mathrm{Be}(\mathrm{c})+$ $\mathrm{N}_{2}(\mathrm{~g}) \rightarrow \mathrm{Be}_{3} \mathrm{~N}_{2}(\mathrm{c})$ giving $\mathrm{Be}(\mathrm{c})+\mathrm{l} / 2 \mathrm{O}_{2}(\mathrm{~g}) \rightarrow \mathrm{BeO}(\mathrm{c})$. We may then relate the $\Delta H f^{\circ}$ 's of other compounds of that element to the selected compound by enthalpies of reaction.

If however every subsequent $\Delta H f^{\circ}$ calculated is dependent upon the value selected for one compound, although we have internal consistency, we have no crosscheck as to how good the original value is. We should then have a second compound whose $\Delta H f^{\circ}$ can also be obtained independently and an enthalpy of reaction relating the two to corroborate the choices and to close the cycle.

Until the recent measurements of Kilday, Prosen, and Wagman [1] ${ }^{1}$ on the enthalpies of solution of

\footnotetext{
${ }^{1}$ Figures in brackets indicate the literature references at end of this paper.
}

$\mathrm{BeO}(\mathrm{c})$ in aqueous $\mathrm{HF}$ solutions and the measurements of Churney and Armstrong [2] on the direct determination of the $\Delta H f^{\circ}\left[\mathrm{BeF}_{2}\right.$ (amorph)], the data available on the direct enthalpies of formation of $\mathrm{BeO}(\mathrm{c})$ and $\mathrm{BeF}_{2}(\mathrm{c})$ and the data linking these values were discordant. These new investigations are a significant aid in establishing the values for $\mathrm{BeO}(\mathrm{c})$ and $\mathrm{BeF}_{2}(\mathrm{c})$ with more certainty. Our main efforts then, after considering the direct determinations, center upon the use of the solution measurements of $\mathrm{BeO}(\mathrm{c})$ in $\mathrm{HF}(\mathrm{aq})$ together with the solution measurements of $\mathrm{Be}(\mathrm{c})$ in $\mathrm{HF}(\mathrm{aq})$ which previously could not be fully utilized to obtain indirectly a definitive value for the $\Delta H F^{\circ}[\mathrm{BeO}(\mathrm{c})]$ and to relate that value to the determinations on the $\Delta H F^{\circ}\left[\mathrm{BeF}_{2}(\mathrm{c})\right]$. Figure 1 schematically presents the reactions and paths discussed in this paper.

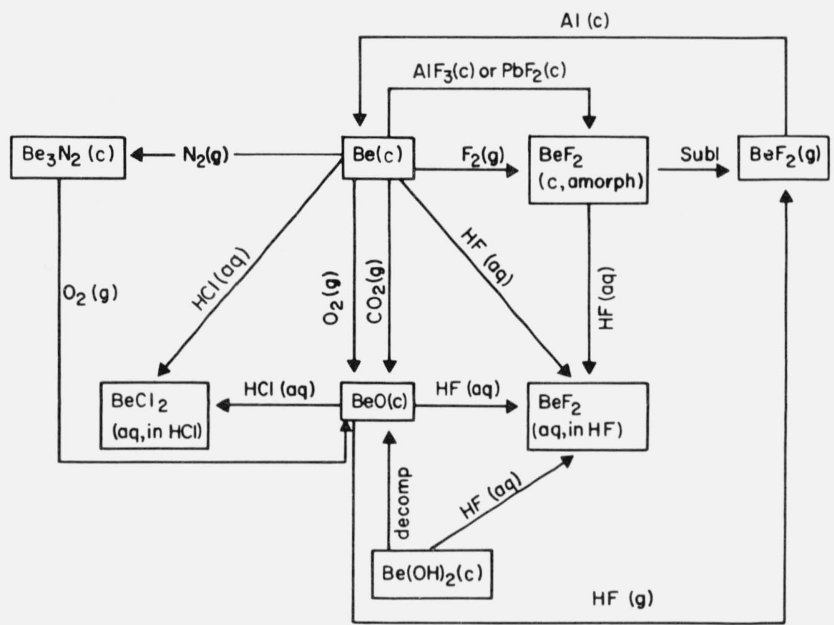

FIGURE 1: The schematic presentation of the relationships involved in the evaluation of $\Delta \mathrm{Hf}^{\circ}[\mathrm{BeO}(\mathrm{c})]$ and $\Delta \mathrm{Hf}^{\circ}\left[\mathrm{BeF}_{2}(\mathrm{c})\right]$. 
All auxiliary data and constants used in the calculations are given in Wagman et al. [3]. Unless otherwise specified the values quoted are at, or have been corrected to, $298.15 \mathrm{~K}$. Our final selections are reported in both $\mathrm{kJ} \cdot \mathrm{mol}^{-1}$ and $\mathrm{kcal} \cdot \mathrm{mol}^{-1}$. However, since this evaluation is included in Parker, Wagman, and Evans [3], where values are expressed in $\mathrm{kcal} \cdot \mathrm{mol}^{-1}$, we report the individual values and their corrections in the same units in order to preserve the consistency of the relationships.

\section{Discussion of Data on $\mathrm{BeO}(\mathrm{c})$}

\subsection{Bomb Combustion}

The following values of $\Delta H\left(\mathrm{kcal} \cdot \mathrm{mol}^{-1}\right)$ for the oxidation of $\mathrm{Be}(\mathrm{c})$ have been reported: Moose and Parr [4], - 134.4; Roth, Börger, and Siemonsen [5], - 147.3; Neumann, Kröger, and Kunz [6], - 145.3; Mielenz and v. Wartenberg [7], - 136.2; and Cosgrove and Snyder [8], -143.1. Neumann, Kröger, and Kunz [6] measured the enthalpy of combustion of $\mathrm{Be}_{3} \mathrm{~N}_{2}$ (crystal form unspecified) to form $\mathrm{BeO}(\mathrm{c})$ and $\mathrm{N}_{2}(\mathrm{~g})$ as $-300.6 \mathrm{kcal} \cdot \mathrm{mol}^{-1}$ of $\mathrm{Be}_{3} \mathrm{~N}_{2}(\mathrm{c})$. Neumann, Kröger, and Haebler [9] directly determined $\Delta H f^{\circ}\left[\mathrm{Be}_{3} \mathrm{~N}_{2}(\mathrm{c})\right]$ $=-134.1$. By difference we obtain $\Delta H f^{\circ}[\mathrm{BeO}(\mathrm{c})]$ $=-144.9$. Of these determinations the Cosgrove and Snyder measurement appeared to be the best value and had been generally accepted; however, the measurements of Kolesov, Popov, and Skuratov [10] on the enthalpies of reaction of $\mathrm{BeO}(\mathrm{c})$ in aqueous $\mathrm{HF}$ and $\mathrm{BeF}_{2}(\mathrm{c})$ in aqueous $\mathrm{HF}$ indicate that the value for $\Delta H f^{\circ}[\mathrm{BeO}(\mathrm{c})]$ should be more negative. This is in line with the fact that Cosgrove and Snyder did not determine the completeness of the reaction; incomplete combustion would cause the value, based on the weight of metal taken, to be too positive. We turn therefore to the indirect determinations of $\Delta H f^{\circ}[\mathrm{BeO}(\mathrm{c})]$.

\subsection{The Enthalpies of Solution of $\mathrm{Be}(\mathrm{c})$ and $\mathrm{BeO}(\mathrm{c})$ in Aqueous HF Solutions}

Matignon and Marchal [11] measured the enthalpies of solution of $\mathrm{Be}(\mathrm{c})$ and $\mathrm{BeO}(\mathrm{c})$ in 30 percent $\mathrm{HF}$ solutions, as have Copaux and Philips [12]. By difference, we obtain for $\mathrm{Be}(\mathrm{c})+\mathrm{H}_{2} \mathrm{O}(\mathrm{liq}) \rightarrow \mathrm{BeO}(\mathrm{c})+\mathrm{H}_{2}$ (g), $\Delta H^{\circ}=-70.9$ and $-62.1 \mathrm{kcal}$, or $\Delta H f^{\circ}[\mathrm{BeO}(\mathrm{c})]=$ -139.2 and $-130.4 \mathrm{kcal} \cdot \mathrm{mol}^{-1}$, respectively. The individual $\Delta H$ 's for solution of $\mathrm{Be}(\mathrm{c})$ in 30 percent $\mathrm{HF}$ are -94.2 from Matignon and Marchal and -82.2 $\mathrm{kcal} \cdot \mathrm{mol}^{-1}$ from Copaux and Philips. For solution of $\mathrm{BeO}(\mathrm{c})$ they are -23.3 and $-20.1 \mathrm{kcal} \cdot \mathrm{mol}^{-1}$, respectively. More recently, Bear and Turnbull [13] measured the enthalpy of solution of $\mathrm{Be}(\mathrm{c})$ in $12,22.6$, 30 , and 40 percent HF solutions. The values are $-101.5,-101.0,-100.5$, and -100.5 kcal. Armstrong and Coyle [14] reported $-99.6 \mathrm{kcal}$ for solution in 25 percent $\mathrm{HF}$. For solution of $\mathrm{BeO}(\mathrm{c})$ in aqueous $\mathrm{HF}$ we also have the results of Kilday et al., e.g., $-24.2 \mathrm{kcal}$ in a 30 percent HF solution, the results of Kolesov et al., in a 23 percent HF solution, -24.1 kcal, and Fricke and Wüllhorst [15] $-24.3 \mathrm{kcal}$ in
12 percent HF. It appears that the measurements of Matignon and Marchal and Copaux and Philips are not reliable; they give little information as to the experimental details and purity of materials. We cannot rely upon the values for $\Delta H f^{\circ}[\mathrm{BeO}(\mathrm{c})]$ obtained from the data of either Matignon and Marchal [11] or Copaux and Philips [12], but a judicious combination of the other measurements can yield a more reliable value.

One of the problems associated with combining reactions of $\mathrm{Be}(\mathrm{c})$ and $\mathrm{BeO}(\mathrm{c})$ in aqueous $\mathrm{HF}$ is that in most cases the final solutions are not the same. Not only are there no quantitative data on what $\mathrm{Be}$ species are in the final solutions or the percent of each, there are also no direct data on the $\Delta H_{\text {diln }}$ or $\Delta H_{\text {mix }}$ of these species in HF solutions. The measurements of Kilday et al., however, provide some insight into the effect of having solutions that do differ in both the amount and concentration of the excess $\mathrm{HF}(\mathrm{aq})$.

They have also measured the differential enthalpy of dilution in two of their final solutions,

\section{$\mathrm{H}_{2} \mathrm{O}($ liq $)+\left[\mathrm{BeF}_{2}\right.$ in excess $\left.\mathrm{HF} \cdot n \mathrm{H}_{2} \mathrm{O}\right] \rightarrow$}

$$
\left[\mathrm{BeF}_{2}+\mathrm{H}_{2} \mathrm{O} \text { in excess } \mathrm{HF} \cdot n \mathrm{H}_{2} \mathrm{O}\right] \text {. }
$$

These measurements are important since $\mathrm{H}_{2} \mathrm{O}$ (in $\mathrm{BeF}_{2}$ $+\mathrm{HF} \cdot n \mathrm{H}_{2} \mathrm{O}$ ) is formed in the reaction of $\mathrm{BeO}(\mathrm{c})$ with $\mathrm{HF}(\mathrm{aq})$, i.e.,

$$
\mathrm{BeO}(\mathrm{c})+2 \mathrm{HF}(\mathrm{aq}) \rightarrow\left[\mathrm{BeF}_{2}+\mathrm{H}_{2} \mathrm{O}\right] \text { in excess } \mathrm{HF} .
$$

We have compared the experimental data with those calculated from the slope $d \varphi_{L} / d m^{1 / 2}$ of $\varphi_{L}$ HF at $n_{f}$ $\mathrm{H}_{2} \mathrm{O}$ from the values ${ }^{2}$ tabulated by Parker [16]. These values are: at $n_{f}=2.68, \bar{L}_{1}\left(\mathrm{cal} \cdot \mathrm{mol}^{-1}\right)=-178$ (calc.), and $-160 \pm 10$ (experimental); at $n_{f}=3.57, \bar{L}_{1}=-110$ (calc.) and $-85 \pm 5$ (experimental). Since the agreement is good, we decided to ignore the presence of the $\mathrm{BeF}_{2}$ in the final solutions and treat the solutions as if they were HF solutions. Since $X$ (the ratio of $\mathrm{HF}$ to $\mathrm{BeF}_{2}$ in the final solution) $\geqq 50$ this is not an unreasonable approach.

We can now set up the equation for the reaction ${ }^{3}$ in the form,

$$
\begin{aligned}
& \mathrm{BeO}(\mathrm{c})+(X+2)(\mathrm{HF}+\left.n_{i} \mathrm{H}_{2} \mathrm{O}\right) \rightarrow \\
& {\left[\mathrm{BeF}_{2}+\mathrm{H}_{2} \mathrm{O}+X\left(\mathrm{HF}+n_{f}^{\prime} \mathrm{H}_{2} \mathrm{O}\right)\right] }
\end{aligned}
$$

and use the experimental $\bar{L}_{1}$ values and the $\varphi_{L}$ values at the appropriate concentrations from [16] to calculate $\Delta\left(\Delta H f^{\circ}\right)$ which represents $\Delta H f^{\circ}[\mathrm{BeO}(\mathrm{c})]-\Delta H f$ $\left[\mathrm{BeF}_{2}(\mathrm{aq})\right]$. Table 1 shows the results as a function of $n_{f}$ where $n_{f}$ is the final ratio of $\mathrm{H}_{2} \mathrm{O}$ to HF. It includes the mole of $\mathrm{H}_{2} \mathrm{O}$ formed. All of their experimental $\Delta H$ 's

\footnotetext{
${ }^{2} \varphi_{L}$ is the relative apparent molal enthalpy. It is the negative of the integral enthalpy of dilution per mole of solute of a solution at concentration $m$ to an infinitely dilute solution. $L_{1}$ is the partial or differential enthalpy of dilution, per mole of solvent, when it is added to a large volume of solution at the given concentration.

${ }^{3} n_{f}^{\prime}=n_{i}(X+2) / X$; it excludes the mole of $\mathrm{H}_{2} \mathrm{O}$ formed. $n_{i}$ is the initial mole ratio of $\mathrm{H}_{2} \mathrm{O}$ to $\mathrm{HF} . X$ is the mole ratio of $\mathrm{HF}$ to $\mathrm{BeF}_{2}$ in solution.
} 


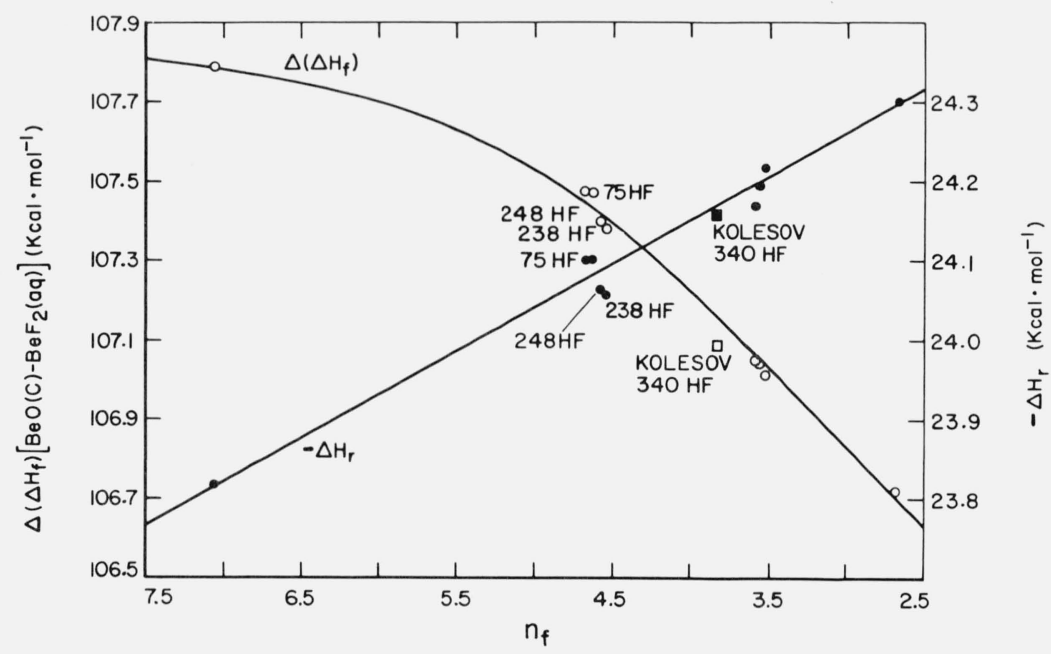

Figure 2: The $\Delta \mathrm{Hr}[\mathrm{BeO}(\mathrm{c})]$ and $\Delta(\Delta \mathrm{Hf})\left[\mathrm{BeO}(\mathrm{c})-\mathrm{BeF}_{2}(\mathrm{aq})\right]$ (uncorrected for the variation in $\mathrm{X}$ ) as a function of the concentration of $\mathrm{HF}$ in the final solution $\left(\mathrm{HF}+\mathrm{n}_{\mathrm{f}} \mathrm{H}_{2} \mathrm{O}\right)$.

For $\Delta H_{r}:$ data of Kilday et al.

For $\Delta(\Delta H f):$ data of Kolesov et al.

$\square$ data of Kolesov et al.

are included, corrected to $298.15 \mathrm{~K}$ where necessary, using the temperature coefficient given in their work. The number in the first column corresponds to the number of the Kilday et al., experiment.

The values for $\Delta(\Delta H f)$ within each group are in excellent agreement with one another, within the precision of the experimental data although there are some differences in $X$ and $n_{f}$ in the final solutions. The values appear to be primarily dependent upon the concentration of $\mathrm{HF}$ within the range $50 \leqq X \leqq 250$. Figure 2 shows a plot of $\Delta(\Delta H f)$ as a function of $n_{f}$. For the $\Delta(\Delta H f)$ we obtain a smooth curve. The smoothed values are also given in table 1 . The variation of $\Delta H$ as a function of the concentration of $\mathrm{HF}$ without regard to the variation of $X$ may be expressed as $\Delta H=$ $-24.092-0.113\left(4.50-n_{f}\right) \mathrm{kcal} \cdot \mathrm{mol}^{-1}$ for $7.1>n_{f}>2.6$.

Kolesov, Popov, and Skuratov [10] also measured the enthalpy of solution of $\mathrm{BeO}(\mathrm{c})$ in aqueous $\mathrm{HF}$. Their reaction corresponds to:

$$
\begin{aligned}
& \mathrm{BeO}(\mathrm{c})+342\left(\mathrm{HF}+3.801 \mathrm{H}_{2} \mathrm{O}\right) \rightarrow \\
& {\left[\mathrm{BeF}_{2}+\mathrm{H}_{2} \mathrm{O}+340\left(\mathrm{HF}+3.823 \mathrm{H}_{2} \mathrm{O}\right)\right] .}
\end{aligned}
$$

The $\Delta H=-24.158 \mathrm{kcal} \cdot \mathrm{mol}^{-1}$ of $\mathrm{BeO}(\mathrm{c})$ results in $\Delta(\Delta H f)=107.085 \mathrm{kcal} \cdot \mathrm{mol}^{-1}$ (using the same treatment as before). From our straight line plot of $\Delta H$ from Kilday et al.'s data, we obtain -24.168 kcal. $\mathrm{mol}^{-1}$ where the final solution contains $\mathrm{BeF}_{2}$ in $90\left(\mathrm{HF}+3.826 \mathrm{H}_{2} \mathrm{O}\right)$. From our plot of $\Delta(\Delta H f)$ versus $n_{f}$ we obtain $\Delta(\Delta H f)=107.185 \mathrm{kcal} \cdot \mathrm{mol}^{-1}$. The agreement in $\Delta H$ is excellent, fortuitously so; in $\Delta\left(\Delta H f^{\circ}\right)$ it is not, but still within the experimental uncertainties. In addition $X$ differs by 250 moles HF in the two solutions.

Kilday and Churney, private communication (1971), also made some measurements on the enthalpy of solution of $\mathrm{BeF}_{2}$ (amorph) in $\mathrm{HF}$ concentrations of
$3.63 \mathrm{H}_{2} \mathrm{O}$ and $5.06 \mathrm{H}_{2} \mathrm{O}$ where $X$ varied from 400 to 2700. From these measurements we obtain the following:

$$
\begin{aligned}
& \Delta H_{\text {soln }}=-8,430+0.50 \mathrm{X} \mathrm{cal} \cdot \mathrm{mol}^{-1} \text { for } n=3.63 \\
& \Delta H_{\text {soln }}=-8,680+0.60 \mathrm{X} \mathrm{cal} \cdot \mathrm{mol}^{-1} \text { for } n=5.06 .
\end{aligned}
$$

Although the precision of these measurements is not high they do enable us to obtain an approximate correction to $\Delta(\Delta H f)$ for the variation in $X$. As a reference solution we have chosen this $X$ to be 100 and have added $-0.55(100-X) \mathrm{cal} \cdot \mathrm{mol}^{-1}$ (an

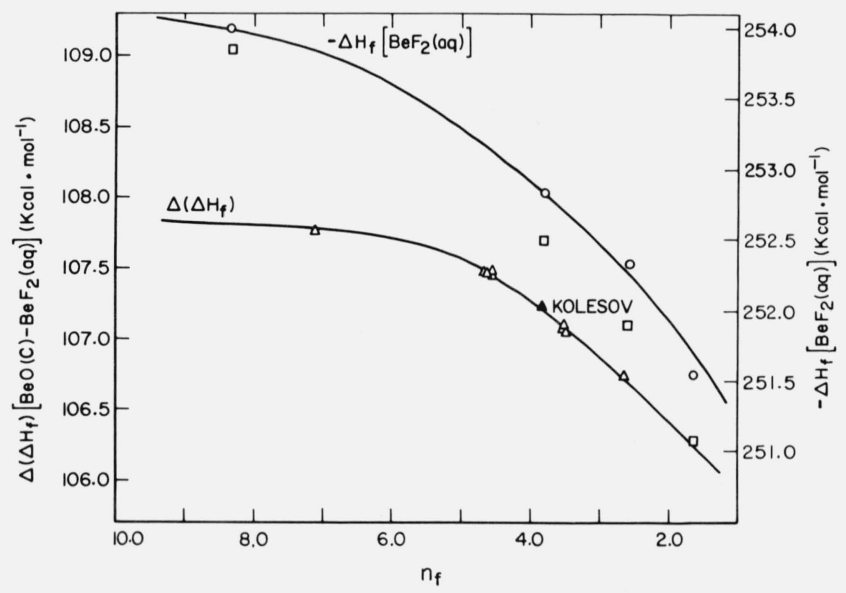

Figure 3: The $\Delta(\Delta \mathrm{Hf})\left\lceil\mathrm{BeO}(\mathrm{c})-\mathrm{BeF}_{2}(\mathrm{aq})\right\rceil$ and the $\Delta \mathrm{Hf}\left[\mathrm{BeF}_{2}(\mathrm{aq})\right]$ as a function of the concentration of $\mathrm{HF}$ in the final solution $\left(\mathrm{HF}+\mathrm{n}_{\mathrm{f}} \mathrm{H}_{2} \mathrm{O}\right)$.

For $\Delta(\Delta H f): \triangle$ Kilday et al. data, corrected to $X=100$.

For $\Delta H f\left[\mathrm{BeF}_{2}(\mathrm{aq})\right]: \bigcirc$ Bear and Turnbull data, corrected to $X=100$

Bear and Turnbull data, uncorrected for variation in $X$. 
TABLE 1. Data derived from measurements of Kilday et al.

\begin{tabular}{|c|c|c|c|c|c|c|c|c|c|c|c|}
\hline 1 & 2 & 3 & 4 & 5 & 6 & 7 & 8 & 9 & 10 & 11 & 12 \\
\hline No. & $\begin{array}{l}\% \mathrm{HF} \text { in } \\
\text { initial } \\
\text { solution }\end{array}$ & $-\Delta H_{298.15 \mathrm{~K}}^{\mathrm{a}}$ & $X$ & $n_{f}$ & $\begin{array}{c}\Delta(\Delta H f) \\
{[\mathrm{BeO}(\mathrm{c})-} \\
\left.-\mathrm{BeF}_{2}(\mathrm{aq})\right]\end{array}$ & $\begin{array}{c}\text { Mean } \\
\Delta(\Delta H f)\end{array}$ & $\begin{array}{c}\text { Mean } \\
n_{f}\end{array}$ & $\begin{array}{c}\Delta(\Delta H f) \\
\text { from smooth } \\
\text { curve, fig. } 2\end{array}$ & $\begin{array}{c}\Delta(\Delta H f) \\
\text { corrected } \\
\text { to } X=100\end{array}$ & $\begin{array}{c}\text { Mean } \\
\Delta(\Delta H f)\end{array}$ & $\begin{array}{c}\Delta(\Delta H f) \\
\text { from smooth } \\
\text { curve, fig. } 3\end{array}$ \\
\hline $\begin{array}{l}20 \\
22 \\
23 \\
24\end{array}$ & 29.76 & $\begin{array}{c}k c a l \cdot \mathrm{mol}^{-1} \\
24.301 \\
24.292 \\
24.315 \\
24.299\end{array}$ & $\begin{array}{l}112.58 \\
117.42 \\
113.12 \\
113.16\end{array}$ & $\begin{array}{l}2.6765 \\
2.6742 \\
2.6762 \\
2.6762\end{array}$ & $\begin{array}{c}\mathrm{kcal} \cdot \mathrm{mol}^{-1} \\
106.710 \\
106.707 \\
106.731 \\
106.714\end{array}$ & $\begin{array}{c}\mathrm{kcal} \cdot \mathrm{mol}^{-1} \\
106.716\end{array}$ & 2.676 & $\begin{array}{c}\mathrm{kcal} \cdot \mathrm{mol}^{-1} \\
106.70\end{array}$ & 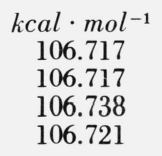 & $\begin{array}{c}k \mathrm{cal} \cdot \mathrm{mol}^{-1} \\
106.723\end{array}$ & $\begin{array}{c}\mathrm{kcal} \cdot \mathrm{mol}^{-1} \\
106.71\end{array}$ \\
\hline $\begin{array}{l}2 \\
4 \\
5\end{array}$ & 24.33 & $\begin{array}{l}24.200 \\
24.221 \\
24.235\end{array}$ & $\begin{array}{r}94.60 \\
96.47 \\
107.53\end{array}$ & $\begin{array}{l}3.5374 \\
3.5359 \\
3.5274\end{array}$ & $\begin{array}{l}107.041 \\
107.055 \\
107.057\end{array}$ & 107.051 & 3.534 & 107.07 & $\begin{array}{l}107.038 \\
107.053 \\
107.061\end{array}$ & 107.051 & 107.07 \\
\hline $\begin{array}{l}25 \\
26 \\
27 \\
28 \\
29 \\
30\end{array}$ & 24.23 & $\begin{array}{l}24.221 \\
24.197 \\
24.176 \\
24.202 \\
24.182 \\
24.187\end{array}$ & $\begin{array}{r}93.05 \\
97.97 \\
94.17 \\
91.36 \\
114.23 \\
92.47\end{array}$ & $\begin{array}{l}3.5581 \\
3.5538 \\
3.5571 \\
3.5597 \\
3.5423 \\
3.5586\end{array}$ & $\begin{array}{l}107.109 \\
107.082 \\
107.064 \\
107.096 \\
107.057 \\
107.071\end{array}$ & 107.080 & 3.555 & 107.08 & $\begin{array}{l}107.105 \\
107.081 \\
107.061 \\
107.091 \\
107.065 \\
107.067\end{array}$ & 107.078 & 107.08 \\
\hline $\begin{array}{r}1 \\
3 \\
9 \\
10\end{array}$ & 24.13 & $\begin{array}{l}24.183 \\
24.141 \\
24.163 \\
24.183\end{array}$ & $\begin{array}{l}88.82 \\
95.48 \\
94.19 \\
93.52\end{array}$ & $\begin{array}{l}3.5817 \\
3.5753 \\
3.5765 \\
3.5771\end{array}$ & $\begin{array}{l}107.113 \\
107.070 \\
107.103 \\
107.072\end{array}$ & 107.090 & 3.578 & 107.09 & $\begin{array}{l}107.112 \\
107.068 \\
107.100 \\
107.068\end{array}$ & 107.087 & 107.09 \\
\hline 7 & 19.80 & 24.103 & 75.23 & 4.6310 & 107.475 & 107.475 & 4.631 & 107.46 & 107.461 & 107.461 & 107.47 \\
\hline $\begin{array}{l}11 \\
13 \\
18\end{array}$ & 19.80 & $\begin{array}{l}24.055 \\
23.955 \\
24.089\end{array}$ & $\begin{array}{l}234.68 \\
232.05 \\
247.99\end{array}$ & $\begin{array}{l}4.5407 \\
4.5412 \\
4.5384\end{array}$ & $\begin{array}{l}107.389 \\
107.296 \\
107.448\end{array}$ & 107.378 & 4.540 & 107.43 & $\begin{array}{l}107.463 \\
107.369 \\
107.529\end{array}$ & 107.454 & 107.44 \\
\hline $\begin{array}{l}6 \\
8\end{array}$ & 19.66 & $\begin{array}{l}24.108 \\
24.091\end{array}$ & $\begin{array}{l}76.47 \\
74.60\end{array}$ & $\begin{array}{l}4.6699 \\
4.6731\end{array}$ & $\begin{array}{l}107.473 \\
107.462\end{array}$ & 107.468 & 4.672 & 107.47 & $\begin{array}{l}107.460 \\
107.452\end{array}$ & 107.456 & 107.48 \\
\hline $\begin{array}{l}12 \\
17 \\
19\end{array}$ & 19.66 & $\begin{array}{l}24.062 \\
24.158 \\
23.968\end{array}$ & $\begin{array}{l}237.12 \\
256.22 \\
251.47\end{array}$ & $\begin{array}{l}4.5806 \\
4.5773 \\
4.5781\end{array}$ & $\begin{array}{l}107.397 \\
107.497 \\
107.318\end{array}$ & 107.404 & 4.579 & 107.44 & $\begin{array}{l}107.472 \\
107.583 \\
107.401\end{array}$ & 107.485 & 107.46 \\
\hline $\begin{array}{l}14 \\
15 \\
16\end{array}$ & 14.05 & $\begin{array}{l}23.787 \\
23.862 \\
23.794\end{array}$ & $\begin{array}{l}53.85 \\
55.49 \\
54.42\end{array}$ & $\begin{array}{l}7.0644 \\
7.0563 \\
7.0616\end{array}$ & $\begin{array}{l}107.753 \\
107.830 \\
107.764\end{array}$ & 107.782 & 7.061 & 107.78 & $\begin{array}{l}107.728 \\
107.806 \\
107.739\end{array}$ & 107.758 & 107.78 \\
\hline
\end{tabular}

${ }^{a}$ Corrected for $\mathrm{BeSO}_{4}$ impurity. 
I ABLE 2. Nata derived from the measurements of Bear and Turnbull and the corresponding values from Kilday et al.

\begin{tabular}{|c|c|c|c|c|c|c|c|c|c|c|}
\hline 1 & 2 & 3 & 4 & 5 & 6 & 7 & 8 & 9 & 10 & 11 \\
\hline$\% \mathrm{HF}$ & $X$ & $n_{f}$ & $\begin{array}{l}\Delta H r^{\circ} \\
\operatorname{Be}(\mathrm{c})\end{array}$ & $\begin{array}{c}\Delta H f \\
{\left[\mathrm{BeF}_{2}(\mathrm{aq})\right]}\end{array}$ & $\begin{array}{c}\Delta H r^{\circ} \\
\text { of } \mathrm{BeO}(\mathrm{c}) \\
\text { st. line } \\
\text { plot, fig. } 2\end{array}$ & $\begin{array}{c}X \\
\text { for }(6)\end{array}$ & $\begin{array}{c}\bar{L}_{1} \\
\mathrm{H}_{2} \mathrm{O}\end{array}$ & $\begin{array}{c}\Delta(\Delta H f) \\
{[\mathrm{BeO}-} \\
\left.\mathrm{BeF}_{2}(\mathrm{aq})\right] \\
\text { fig. } 2\end{array}$ & $\begin{array}{c}\Delta H f \\
{\left[\mathrm{BeF}_{2}(\mathrm{aq})\right]} \\
\text { corrected } \\
\text { to } X=100\end{array}$ & $\begin{array}{c}\Delta(\Delta H f) \\
{[\mathrm{BeO}(\mathrm{c})-} \\
\left.\mathrm{BeF}_{2}(\mathrm{aq})\right] \\
\text { fig. } 3\end{array}$ \\
\hline $\begin{array}{l}12 \\
22.6 \\
30 \\
40\end{array}$ & $\begin{array}{r}358 \\
677 \\
899 \\
1079\end{array}$ & $\begin{array}{l}8.184 \\
3.811 \\
2.597 \\
1.670\end{array}$ & $\begin{array}{c}\text { kcal } \cdot \mathrm{mol}^{-1} \\
-101.47 \\
-101.02 \\
-100.52 \\
-100.5\end{array}$ & $\begin{array}{c}\mathrm{kcal} \cdot \mathrm{mol}^{-1} \\
-253.84 \\
-252.51 \\
-251.89 \\
\mathrm{a}-251.0\end{array}$ & $\begin{array}{c}\text { kcal } \cdot \mathrm{mol}^{-1} \\
-23.68 \\
-24.17 \\
-24.31 \\
-24.42\end{array}$ & $\begin{array}{r}50 \\
90 \\
115 \\
130\end{array}$ & $\begin{array}{c}k c a l \cdot \mathrm{mol}^{-1} \\
0 \\
-0.07 \\
-0.18 \\
-0.3 \\
(\text { est'd) }\end{array}$ & $\begin{array}{c}\mathrm{kcal} \cdot \mathrm{mol}^{-1} \\
107.81 \\
107.18 \\
106.68 \\
106.2\end{array}$ & $\begin{array}{c}k c a l \cdot \mathrm{mol}^{-1} \\
-253.98 \\
-252.83 \\
-252.33 \\
-251.54\end{array}$ & $\begin{array}{c}\text { kcal } \cdot \mathrm{mol}^{-1} \\
107.78 \\
107.18 \\
106.68 \\
106.2\end{array}$ \\
\hline
\end{tabular}

a This is based on an estimate for $\Delta H_{\text {diln }}=-0.9 \mathrm{kcal} \cdot \mathrm{mol}^{-1}$ for $1079\left(\mathrm{HF}+1.666 \mathrm{H}_{2} \mathrm{O}\right) \rightarrow 1079\left(\mathrm{HF}+1.670 \mathrm{H}_{2} \mathrm{O}\right)$ and $\varphi_{L}$ for $\mathrm{HF}+1.666 \mathrm{H}_{2} \mathrm{O}$ $=3.8 \mathrm{kcal} \cdot \mathrm{mol}^{-1}$.

TABLE 3. $\Delta \mathrm{Hf}^{\circ}[\mathrm{BeO}(\mathrm{c})]$ in $\mathrm{kcal} \cdot \mathrm{mol}^{-1}$ as calculated by various methods from data in table 2

\begin{tabular}{ccc}
\hline \hline $\begin{array}{c}\text { Method 1 } \\
(4,6, \text { and } 8)\end{array}$ & $\begin{array}{c}\text { Method 2 } \\
(5 \text { and 9) }\end{array}$ & $\begin{array}{c}\text { Method 3 } \\
(10 \text { and 11) }\end{array}$ \\
\hline-146.11 & -146.03 & -146.20 \\
-145.24 & -145.33 & -145.65 \\
-144.70 & -145.21 & -145.65 \\
-144.7 & -144.8 & -145.3 \\
\hline
\end{tabular}

average value) to the $\Delta(\Delta H f)$ 's (see table 1 , columris 10,11 , and 12 and fig. 3 ). The new $\Delta(\Delta H f)$ 's are in slightly better agreement with one another. For the $\Delta\left(\Delta H f^{\circ}\right)$ from Kolesov et al., we obtain 107.217 $\mathrm{kcal} \cdot \mathrm{mol}^{-1}$ as compared to 107.180 from figure 3 , in much better agreement; this lends support to the use of this treatment on the Bear and Turnbull measurements [13] on $\mathrm{Be}(\mathrm{c})$ in excess HF solutions, where the final ratio of $\mathrm{HF}$ to $\mathrm{BeF}_{2}$ is greater than 340 .

Bear and Turnbull used solutions of $12,22.6,30$, and 40 percent $\mathrm{HF}$. Their results can be treated three ways:

(1) using their $\Delta H_{r}$ with the $\Delta H_{r}$ from our straight line plot of the Kilday et al., data on $\mathrm{BeO}_{-}$in $\mathrm{HF}$ at the appropriate $n_{f}$, with the experimental $\bar{L}_{1}$, obtaining the reaction, $\mathrm{Be}(\mathrm{c})+\mathrm{H}_{2} \mathrm{O}(\mathrm{aq}) \rightarrow \mathrm{BeO}(\mathrm{c})+\mathrm{H}_{2}(\mathrm{~g})$;

(2) calculating the $\Delta H f^{\circ}\left[\mathrm{BeF}_{2}\right.$ in $\left.X\left(\mathrm{HF}+n_{f} \mathrm{H}_{2} \mathrm{O}\right)\right]$ and using the appropriate $\Delta(\Delta H f)\left[\mathrm{BeO}-\mathrm{BeF}_{2}(\mathrm{aq})\right]$ at $n_{f}$ from figure 2;

(3) correcting $\Delta H f\left[\mathrm{BeF}_{2}(\mathrm{aq})\right]$ to $X=100$ and using the comparable corrected $\Delta(\Delta H f)$ from figure 3 .

The results are summarized in tables 2 and 3 . It is obvious that the values for $\Delta H f^{\circ}[\mathrm{BeO}(\mathrm{c})]$ are in better agreement using the third way of calculating. Figure 3 shows a plot of $\Delta H f\left[\mathrm{BeF}_{2}(\mathrm{aq})\right.$, in $\left.100\left(\mathrm{HF}+n_{f} \mathrm{H}_{2} \mathrm{O}\right)\right]$ and also the uncorrected values derived from the Bear and Turnbull measurements.

For confirmation of the above values we may use the enthalpy of solution of the samples of $\mathrm{BeF}_{2}$ (amorph) cited earlier whose $\Delta H f^{\circ}$ is known $\left(-244.3 \mathrm{kcal} \cdot \mathrm{mol}^{-1}\right.$, directly determined by Churney and Armstrong [2]) from which we obtain $\Delta H f\left[\mathrm{BeF}_{2}(\mathrm{aq})\right.$ in $100(\mathrm{HF}+$ $\left.\left.3.63 \mathrm{H}_{2} \mathrm{O}\right)\right]=-252.68 \mathrm{kcal} \cdot \mathrm{mol}^{-1}$ and $\Delta H f\left[\mathrm{BeF}_{2}(\mathrm{aq})\right.$ in $\left.100\left(\mathrm{HF}+5.06 \quad \mathrm{H}_{2} \mathrm{O}\right)\right]=-252.92 \mathrm{kcal} \cdot \mathrm{mol}^{-1}$ (cf -252.75 and $-253.38 \mathrm{kcal} \cdot \mathrm{mol}^{-1}$ from the smoothed curve (fig. 3 ) of Bear and Turnbull's corrected $\Delta H f$ 's). Using $\Delta(\Delta H f)=107.11$ and $\Delta(\Delta H f)=107.57$ $\mathrm{kcal} \cdot \mathrm{mol}^{-1}$ from figure 3 , we obtain $\Delta H f^{\circ} \mathrm{BeO}(\mathrm{c})=$ -145.57 and $-145.35 \mathrm{kcal} \cdot \mathrm{mol}^{-1}$, respectively.

In all the above cases we have used the $\Delta(\Delta H f)$ $\left[\mathrm{BeO}(\mathrm{c})-\mathrm{BeF}_{2}(\mathrm{aq})\right]$ derived from the Kilday et al. measurements. If we use $\Delta(\Delta H f)=107.217 \mathrm{kcal} \cdot \mathrm{mol}^{-1}$ from the Kolesov et al. measurements and $\Delta H f$ $\mathrm{BeF}_{2}(\mathrm{aq})=-252.93 \mathrm{kcal} \cdot \mathrm{mol}^{-1}$ from figure 3 we obtain $\Delta H f^{\circ} \mathrm{BeO}(\mathrm{c})=-145.71 \mathrm{kcal} \cdot \mathrm{mol}^{-1}$.

There is another reaction involving the enthalpy of solution of $\mathrm{Be}(\mathrm{c})$ in $\mathrm{HF}(\mathrm{aq})$, that by Armstrong and Coyle [14]. They reported that there was an unexplained deficiency of $\mathrm{H}_{2}$ on the order of 0.5 percent. They ascribe an uncertainty of not more than 0.2 percent to the enthalpy of reaction for this contribution. The measurements are on the reaction: $\mathrm{Be}(\mathrm{c})$ $+6.470\left(\mathrm{HF}+3.309 \mathrm{H}_{2} \mathrm{O}\right) \rightarrow\left[\mathrm{BeF}_{2}+4.470(\mathrm{HF}+4.789\right.$ $\left.\left.\mathrm{H}_{2} \mathrm{O}\right)\right]+\mathrm{H}_{2}(\mathrm{~g})$ for which $\Delta H=-99.64 \mathrm{kcal} \cdot \mathrm{mol}^{-1}$ and $\Delta H f\left[\mathrm{BeF}_{2}(\mathrm{aq})\right.$ in $\left.4.470\left(\mathrm{HF}+4.789 \mathrm{H}_{2} \mathrm{O}\right)\right]=-251.1$ $\mathrm{kcal} \cdot \mathrm{mol}^{-1}$. Using the same three approaches as for Bear and Turnbull's data we obtain $\Delta H f^{\circ}[\mathrm{BeO}(\mathrm{c})]$ $=-143.9$ (1); $-143.6(2)$; and $-143.5 \mathrm{kcal} \cdot \mathrm{mol}^{-1}$ (3), where $X$ is corrected to 100 . In all cases we assume that the species in the two solutions are the same; in the third case we also assume our correction is applicable to $X=4.47$, which is probably not justified.

There are two other approaches we can use on their data:

(4) Heretofore we have neglected the effect of the $\mathrm{BeF}_{2}$ on the $\mathrm{HF}$ dilution correction. If we assume that the $\mathrm{BeF}_{2}$ present in the solution may be replaced by an equivalent number of moles of $\mathrm{HF}$ solution, then we may consider the $\mathrm{HF}$ to be in $3.913 \mathrm{H}_{2} \mathrm{O}$. This results in $\Delta H f\left[\mathrm{BeF}_{2}(\mathrm{aq})\right]=-251.4 \mathrm{kcal} \cdot \mathrm{mol}^{-1}$ and $\Delta H f^{\circ}$ $[\mathrm{BeO}(\mathrm{c})]=-143.9 \mathrm{kcal} \cdot \mathrm{mol}^{-1}$.

(5) We can calculate a $\Delta H_{\text {mix }}$ for the addition of more of the initial solution, $\left[\mathrm{HF}+3.309 \mathrm{H}_{2} \mathrm{O}\right]$, to their final solution, using the $\phi_{L}$ values of $\mathrm{HF}$, and obtain:

$$
\begin{array}{r}
{\left[\mathrm{BeF}_{2}(\mathrm{aq})+4.470\left(\mathrm{HF}+4.789 \mathrm{H}_{2} \mathrm{O}\right)\right]} \\
+95\left(\mathrm{HF}+3.309 \mathrm{H}_{2} \mathrm{O}\right) \rightarrow
\end{array}
$$

$\left[\mathrm{BeF}_{2}(\mathrm{aq})+99.470\left(\mathrm{HF}+3.375 \mathrm{H}_{2} \mathrm{O}\right)\right] ; \quad \Delta H_{\text {mix }}=-0.264$ $\mathrm{kcal} \cdot \mathrm{mol}^{-1}$. Combining this with their reported $\Delta H$ leads to:

$\mathrm{Be}(\mathrm{c})+101.470\left(\mathrm{HF}+3.309 \mathrm{H}_{2} \mathrm{O}\right) \rightarrow\left[\mathrm{BeF}_{2}(\mathrm{aq})+99.470\right.$ $\left.\left(\mathrm{HF}+3.375 \mathrm{H}_{2} \mathrm{O}\right)\right]+\mathrm{H}_{2}(\mathrm{~g}) ; \Delta H=-99.95 \mathrm{kcal} \cdot \mathrm{mol}^{-1}$. This value is now in closer agreement with Bear and 
Turnbull's measurements. For the same reaction with $\mathrm{BeO}(\mathrm{c})$ we obtain $\Delta H=-24.22 \mathrm{kcal} \cdot \mathrm{mol}^{-1}$, so that $\Delta H f^{\circ}[\mathrm{BeO}(\mathrm{c})]=-144.1 \mathrm{kcal} \cdot \mathrm{mol}^{-1}$. A variation of this would be to use a $\Delta H_{\text {mix }}$ based on our fourth approach, i.e., to assume the $\mathrm{HF}$ is in $3.913 \mathrm{H}_{2} \mathrm{O}$, then $\Delta H=-100.23$ and $\Delta H f^{\circ}[\mathrm{BeO}(\mathrm{e})]=-144.4 \mathrm{kcal}$. $\mathrm{mol}^{-1}$.

\subsection{The Enthalpies of Solution of $\mathrm{Be}(\mathrm{c})$ and $\mathrm{BeO}(\mathrm{c})$ in Aqueous $\mathrm{HCl}$ Solutions}

The problem of nonidentical final solutions is also present in the $\mathrm{Be}(\mathrm{c})-\mathrm{BeO}(\mathrm{c})-\mathrm{HCl}$ aqueous systems. Kilday et al. [1] have oitained $\Delta H=-12.8$ and -12.7 $\mathrm{kcal} \cdot \mathrm{mol}^{-1}$ for the solution of $\mathrm{BeO}(\mathrm{c})$ in 18 and 22.6 percent $\mathrm{HCl}$, respectively. The complete reactions are:

$$
\mathrm{BeO}(\mathrm{c})+40.9\left(\mathrm{HCl}+9.21 \mathrm{H}_{2} \mathrm{O}\right) \rightarrow\left[\mathrm{BeCl}_{2}(\mathrm{aq})\right.
$$

and

$$
\left.+\mathrm{H}_{2} \mathrm{O}(\mathrm{aq})+38.9\left(\mathrm{HCl}+9.69 \mathrm{H}_{2} \mathrm{O}\right)\right]
$$

$$
\begin{aligned}
\mathrm{BeO}(\mathrm{c})+47.8(\mathrm{HCl}+ & \left.6.93 \mathrm{H}_{2} \mathrm{O}\right) \rightarrow\left[\mathrm{BeCl}_{2}(\mathrm{aq})\right. \\
& \left.+\mathrm{H}_{2} \mathrm{O}(\mathrm{aq})+45.8\left(\mathrm{HCl}+7.23 \mathrm{H}_{2} \mathrm{O}\right)\right] .
\end{aligned}
$$

(The experimental $\bar{L}_{1}$ value $=-272 \mathrm{cal} \cdot \mathrm{mol}^{-1}$ of $\mathrm{H}_{2} \mathrm{O}$ (see ref. [1], sec. 5.4) checks well with the $\bar{L}_{1}$ calculated from the $\phi_{L}$ values of $\mathrm{HCl}$ [16] at $n=7.23 \mathrm{H}_{2} \mathrm{O}$ ).

From these reactions we obtain for $\mathrm{BeCl}_{2}(\mathrm{aq})$ in $38.3\left(\mathrm{HCl}+9.72 \mathrm{H}_{2} \mathrm{O}\right) \Delta(\Delta H f)\left[\mathrm{BeO}(\mathrm{c})-\mathrm{BeCl}_{2}(\mathrm{aq})\right]=$ $18.6 \mathrm{kcal} \cdot \mathrm{mol}^{-1}$ and $16.6 \mathrm{kcal} \cdot \mathrm{mol}^{-1}$ for $\mathrm{BeCl}_{2}(\mathrm{aq})$ in $45.8\left(\mathrm{HCl}+7.25 \mathrm{H}_{2} \mathrm{O}\right)$.

Thompson, Sinke, and Stull [17] reported $\Delta H=$ $-89.61 \mathrm{kcal} \cdot \mathrm{mol}^{-1}$ for $\mathrm{Be}(\mathrm{c})+8.38\left(\mathrm{HCl}+8.111 \mathrm{H}_{2} \mathrm{O}\right) \rightarrow$ $\left[\mathrm{BeCl}_{2}(\mathrm{aq})+6.38\left(\mathrm{HCl}+10.654 \mathrm{H}_{2} \mathrm{O}\right)\right]+\mathrm{H}_{2}(\mathrm{~g})$, from which we obtain $\Delta H f\left[\mathrm{BeCl}_{2}(\mathrm{aq})\right]=-163.79 \mathrm{kcal} \cdot$ mol-1 $^{-1}$. Blachnik, Gross, and Hayman [18] reported $\Delta H_{383 \mathrm{~K}}=-90.00 \mathrm{kcal} / \mathrm{mol}$ for:

$$
\begin{aligned}
\mathrm{Be}(\mathrm{c})+8.86\left(\mathrm{HCl}+7.991 \mathrm{H}_{2} \mathrm{O}\right) & \rightarrow \mathrm{H}_{2}(\mathrm{~g})+\left[\mathrm{BeCl}_{2}(\mathrm{aq})\right. \\
+ & \left.6.86\left(\mathrm{HCl}+10.320 \mathrm{H}_{2} \mathrm{O}\right)\right] .
\end{aligned}
$$

This value, corrected to $298.15 \mathrm{~K}$ is in good agreement with the Thompson et al. value.

Using the same approaches as for $\mathrm{HF}$ we have:

(1) With $\Delta H$ of solution of $\mathrm{BeO}(\mathrm{c}) \approx-12.8 \mathrm{kcal}$ $\cdot \mathrm{mol}^{-1}$ when $n_{f}=10.65, \Delta H f^{\circ}[\mathrm{BeO}(\mathrm{c})]=-145.2 \mathrm{kcal}$ $\cdot \mathrm{mol}^{-1}$.

(2) From an extrapolation of $\Delta\left(\Delta H f^{\circ}\right)[\mathrm{BeO}(\mathrm{c})$ $\left.-\mathrm{BeCl}_{2}(\mathrm{aq})\right]$ we obtain $\Delta\left(\Delta H f^{\circ}\right)=19.4 \mathrm{kcal} \cdot \mathrm{mol}^{-1}$ where the $\mathrm{BeCl}_{2}$ is in $34\left(\mathrm{HCl}+10.65 \mathrm{H}_{2} \mathrm{O}\right)$ and $\Delta H f^{\circ}$ $[\mathrm{BeO}(\mathrm{c})]=-144.4 \mathrm{kcal} \cdot \mathrm{mol}^{-1}$.

(3) Not used since we have no correction for the variation in $X$.

As in our treatment of the Armstrong and Coyle [14] results we may try the following:

(4) If we assume that the $\mathrm{BeCl}_{2}$ present may be replaced by an equivalent number of moles of $\mathrm{HCl}$ solution we may consider the $\mathrm{HCl}$ to be in $9.21 \mathrm{H}_{2} \mathrm{O}$. Then $\Delta H f\left[\mathrm{BeCl}_{2}(\mathrm{aq})\right]=-165.0$ and $\Delta H f[\mathrm{BeO}(\mathrm{c})]$ $=-145.6 \mathrm{kcal} \cdot \mathrm{mol}^{-1}$.
(5) We can calculate a $\Delta H_{\text {mix }}$ by adding more of the initial $\mathrm{HCl}$ solution to the final solution. We obtain:

$$
\begin{aligned}
{\left[\mathrm{BeCl}_{2}(\mathrm{aq})+6.38\left(\mathrm{HCl}+10.654 \mathrm{H}_{2} \mathrm{O}\right)\right]+35.54(\mathrm{HCl}} \\
\left.+8.111 \mathrm{H}_{2} \mathrm{O}\right) \rightarrow\left[\mathrm{BeCl}_{2}(\mathrm{aq})+41.92(\mathrm{HCl}\right. \\
\left.\left.+8.499 \mathrm{H}_{2} \mathrm{O}\right)\right] ; \Delta H=-0.64 \mathrm{kcal} \cdot \mathrm{mol}^{-1}
\end{aligned}
$$

and $\Delta H=-90.3 \mathrm{kcal} \cdot \mathrm{mol}^{-1}$ for:

$$
\begin{aligned}
\mathrm{Be}(\mathrm{c})+43.92\left(\mathrm{HCl}+8.111 \mathrm{H}_{2} \mathrm{O}\right) \rightarrow \mathrm{H}_{2}(\mathrm{~g}) & \\
+ & {\left[\mathrm{BeCl}_{2}(\mathrm{aq})+41.92\left(\mathrm{HCl}+8.499 \mathrm{H}_{2} \mathrm{O}\right)\right] . }
\end{aligned}
$$

For the reaction with $\mathrm{BeO}(\mathrm{c})$ we can say $\Delta H=$ $-12.7 \mathrm{kcal} \cdot \mathrm{mol}^{-1}$ for $\mathrm{BeO}(\mathrm{c})+43.92\left(\mathrm{HCl}+8.111 \mathrm{H}_{2} \mathrm{O}\right)$ $\rightarrow\left[\mathrm{BeCl}_{2}(\mathrm{aq})+\mathrm{H}_{2} \mathrm{O}+41.92\left(\mathrm{HCl}+8.499 \mathrm{H}_{2} \mathrm{O}\right)\right]$, so that $\Delta H=-77.56 \mathrm{kcal} \cdot \mathrm{mol}^{-1}$ for $\mathrm{Be}(\mathrm{c})+\mathrm{H}_{2} \mathrm{O}(\mathrm{aq})$ $\rightarrow \mathrm{BeO}(\mathrm{c})+\mathrm{H}_{2}(\mathrm{~g})$ and $\Delta H f^{\circ} \mathrm{BeO}(\mathrm{c})=-146.0 \mathrm{kcal}$ - $\mathrm{mol}^{-1}$. A variation of this would be to calculate a $\Delta H_{\text {mix }}=-1.81 \mathrm{kcal} \cdot \mathrm{mol}^{-1}$ on the basis of (4). Then $\Delta H$ for the reaction with $\mathrm{Be}(\mathrm{c})=-91.4$ and $\Delta H f^{\circ}[\mathrm{BeO}(\mathrm{c})]$ $=-147.2 \mathrm{kcal} \cdot \mathrm{mol}^{-1}$.

Averaging these five values we obtain $-145.7 \mathrm{kcal}$ $\cdot \mathrm{mol}^{-1}$ for $\Delta H f^{\circ}[\mathrm{BeO}(\mathrm{c})]$.

\subsection{Other data}

From the cell measurements of Smirnov and

\begin{tabular}{|c|c|}
\hline Investigator & $\Delta H f^{\circ}$ \\
\hline 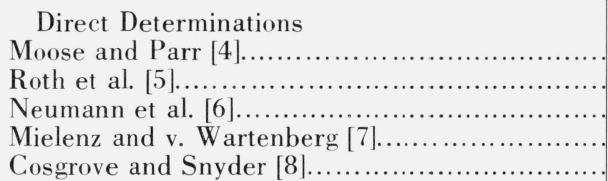 & $\begin{array}{l}\mathrm{kcal} \cdot \mathrm{mol}^{-1} \\
-134.1 \\
-147.3 \\
-145.3 \\
-136.2 \\
-143.1\end{array}$ \\
\hline 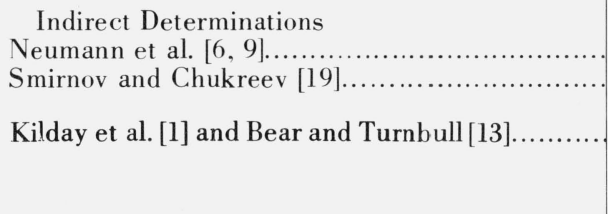 & $\begin{array}{l}-144.9 \\
-141.1 \\
-146.20 \\
-145.65 \\
-145.65 \\
-145.3\end{array}$ \\
\hline 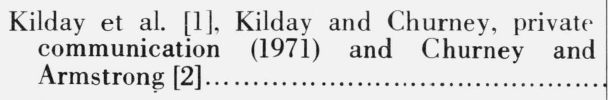 & $\left\{\begin{array}{l}-145.6 \\
-145.4\end{array}\right.$ \\
\hline Kolesov et al. [10] and Bear and Turnbull [13]....... & -145.7 \\
\hline Kilday et al. [1] and Armstrong and Coyle [14].... & -143.9 \\
\hline Kilday et al. [1] and Thompson et al. [17].......... & -145.7 \\
\hline
\end{tabular}
Chukreev [19] in the temperature range 955 to $1313 \mathrm{~K}$, we obtain a second law $\Delta H^{\circ}=-94.6 \mathrm{kcal} \cdot \mathrm{mol}^{-1}$ and a third law $\Delta H^{\circ}=-93.7 \mathrm{kcal} \cdot \mathrm{mol}^{-1}$ for $\mathrm{Be}(\mathrm{c})$ $+1 / 2 \mathrm{CO}_{2}(\mathrm{~g}) \rightarrow \mathrm{BeO}(\mathrm{c})+1 / 2 \mathrm{C}($ graphite $)$, or $\Delta H f^{\circ}$ $[\mathrm{BeO}(\mathrm{c})]=-141.6$ and $-140.8 \mathrm{kcal} \cdot \mathrm{mol}^{-1}$, respectively.

\subsection{The Selection of the $\Delta H f^{\circ}[\mathrm{BeO}(\mathrm{c})]$}

It is appropriate at this point to tabulate the values of $\Delta H f^{\circ} \mathrm{BeO}(\mathrm{c})$, both the direct and indirect determina-

TABLE 4. Summary of values of $\Delta H f^{\circ}[\mathrm{BeO}(\mathrm{c})]$ 
tions (table 4). As is evident, except for the Smirnov and Chukreev value, all the indirect determinations support a more negative value than that of Cosgrove and Snyder. The "best" value now appears to be $-145.7 \mathrm{kcal} \cdot \mathrm{mol}^{-1}$ in good agreement with the Neumann et al. [6] direct determination. The uncertainties are discussed in section 4 .

\subsection{The Decomposition of Beryllium Hydroxide as Supporting Evidence}

Bear and Turnbull [13] have also measured the enthalpy of solution of $\mathrm{Be}(\mathrm{OH})_{2}(\beta$, orthorhombic $)$ and $\mathrm{Be}(\mathrm{OH})_{2}$ ( $\alpha$, tetragonal) in 22.6 percent $\mathrm{HF}$, [679(HF $\left.+3.80 \mathrm{H}_{2} \mathrm{O}\right)$ ]. From these measurements and their measurements on $\mathrm{Be}(\mathrm{c})$ we obtain $\Delta H=-79.83 \mathrm{kcal}$. $\mathrm{mol}^{-1}$ for $\mathrm{Be}(\mathrm{c})+2 \mathrm{H}_{2} \mathrm{O}(\mathrm{liq}) \rightarrow \mathrm{Be}(\mathrm{OH})_{2}(\beta)+\mathrm{H}_{2}(\mathrm{~g})$ and $\Delta H f^{\circ}=-216.5 \mathrm{kcal} \cdot \mathrm{mol}^{-1}$; similarly for $\mathrm{Be}(\mathrm{OH})_{2}(\alpha)$ we obtain $\Delta H=-79.10 \mathrm{kcal} \cdot \mathrm{mol}^{-1}$ and $\Delta H f^{\circ}=-215.7$ $\mathrm{kcal} \cdot \mathrm{mol}^{-1}$. Using these values for $\Delta H f^{\circ}$ and our tentative "best" value for $\mathrm{BeO}(\mathrm{c})$ we obtain:

$\mathrm{BeO}(\mathrm{c})+\mathrm{H}_{2} \mathrm{O}($ liq $) \rightarrow$

$\mathrm{Be}(\mathrm{OH})_{2}(\mathrm{c}, \beta) ; \Delta H^{\circ}=-2.5 \mathrm{kcal} \cdot \mathrm{mol}^{-1}$

$\mathrm{BeO}(\mathrm{c})+\mathrm{H}_{2} \mathrm{O}(\mathrm{liq}) \rightarrow$

$$
\mathrm{Be}(\mathrm{OH})_{2}(\mathrm{c}, \alpha) ; \Delta H^{\circ}=-1.7 \mathrm{kcal} \cdot \mathrm{mol}^{-1} \text {. }
$$

Fricke and Wüllhorst [15] measured the enthalpies of solution of $\mathrm{BeO}(\mathrm{c}), \mathrm{Be}(\mathrm{OH})_{2}(\mathrm{c}, \beta)$, and $\mathrm{Be}(\mathrm{OH})_{2}(\mathrm{c}, \alpha)$ in 11.59 percent HF. From these measurements we obtain $\Delta H^{\circ}=-2.5$ and $-1.8 \mathrm{kcal} \cdot \mathrm{mol}^{-1}$, respectively, in excellent agreement with our $\Delta H^{\circ}$. Matignon and Marchal [20, 21], from measurements in 30 percent $\mathrm{HF}$, obtained $\Delta H_{\mathrm{hyd}}^{\circ}\left(\mathrm{Be}(\mathrm{OH})_{2}\right.$, form unspecified $)=$ $-3.2 \mathrm{kcal} \cdot \mathrm{mol}^{-1}$, in fair agreement. Fricke and Severin [22] measured the equilibrium vapor pressure at $378 \mathrm{~K}$ to be $100 \mathrm{~mm} \mathrm{H}_{2} \mathrm{O}(\mathrm{g})$ over $\mathrm{Be}(\mathrm{OH})_{2}(\mathrm{c}, \beta)$. Using a Nernst equation they calculate $\Delta H=15.5 \mathrm{kcal} \cdot \mathrm{mol}^{-1}$ of $\mathrm{H}_{2} \mathrm{O}(\mathrm{g})$, which results in $\Delta H^{\circ}=-5.0 \mathrm{kcal} \cdot \mathrm{mol}^{-1}$ for the hydration of $\mathrm{BeO}(\mathrm{c})$. However they reported that the $\mathrm{BeO}$ formed had a distorted lattice which should require a $\Delta H f^{\circ}$ more positive than $-145.7 \mathrm{kcal} \cdot \mathrm{mol}^{-1}$. Also since the $\Delta H$ calculated is based on only one point it can not be considered a definitive value.

It is evident that the related data are supportive of our value for $\Delta H f^{\circ}[\mathrm{BeO}(\mathrm{c})]=-145.7 \mathrm{kcal} \cdot \mathrm{mol}^{-1}$.

\section{The Enthalpy of Formation of $\mathrm{BeF}_{2}(\mathrm{c})$}

\subsection{The Enthalpy of Transition of $\mathrm{BeF}_{2}(\mathrm{gl})$ and $\mathrm{BeF}_{2}$ (amorph) to $\mathrm{BeF}_{2}$ ( $\alpha$, quartz)}

There are no published direct determinations of the $\Delta H f^{\circ}\left[\mathrm{BeF}_{2}(\mathrm{c})\right]$ from combustion of $\mathrm{Be}(\mathrm{c})$ in $\mathrm{F}_{2}(\mathrm{~g})$; the combustion of $\mathrm{Be}(\mathrm{c})$ in $\mathrm{F}_{2}(\mathrm{~g})$ results in amorphous material. The indirect reactions, in which $\mathrm{BeF}_{2}$ forms, produce a glassy state.

Taylor and Gardner [23] determined the enthalpy of solution of both the $\alpha$, quartz form, and the glassy form in acetic acid-sodium acetate solutions to be -3.64 and $-4.76 \mathrm{kcal} \cdot \mathrm{mol}^{-1}$, respectively. This leads to a $\Delta H_{\text {trans }}$ quartz $\rightarrow$ glass $=1.12 \mathrm{kcal} \cdot \mathrm{mol}^{-1}$. If we assume that the amorphous and glassy states are equivalent we can convert both to $\Delta H f^{\circ}\left[\mathrm{BeF}_{2}(\alpha\right.$, quartz)].

\subsection{The Reaction of $\mathrm{Be}(\mathrm{c})$ With $\mathrm{F}_{2}$ (g)}

Churney and Armstrong [2] measured the enthalpy of reaction of $\mathrm{Be}(\mathrm{c})$ in $\mathrm{F}_{2}(\mathrm{~g})$ to be $-244.3 \mathrm{kcal} \cdot \mathrm{mol}^{-1}$. They report $\mathrm{BeF}_{2}$ (amorph) to be their product. This results in $\Delta H f^{\circ}\left[\mathrm{BeF}_{2}(\mathrm{c})\right]=-245.4 \mathrm{kcal} \cdot \mathrm{mol}^{-1}$. In a preliminary report (1965) they cite the unpublished measurements of Simmons (1961) on the conversion of $\mathrm{Be}$ (foil) to partially glassy $\mathrm{BeF}_{2}$, leading to $\Delta H f^{\circ}\left[\mathrm{BeF}_{2}(\mathrm{c})\right]=-257.0 \mathrm{kcal} \cdot \mathrm{mol}^{-1}$.

\subsection{The Reaction of $\mathrm{Be}(\mathrm{c})$ With $\mathrm{PbF}_{2}$ (c)}

Gross [24] reported $\Delta H^{\circ}=-84.0 \mathrm{kcal}$ for the reaction of $\mathrm{Be}(\mathrm{c})$ with $\mathrm{PbF}_{2}(\mathrm{c})$ to form $\mathrm{BeF}_{2}(\mathrm{c})$ and $\mathrm{Pb}(\mathrm{c})$. Although no crystallographic identification was made the direction of the results under varying conditions indicates that the value is for the formation of $\mathrm{BeF}_{2}(\mathrm{c})$. Since there is some uncertainty in our selection for $\mathrm{PbF}_{2}(\mathrm{c})$ we will avoid its use by relating the reaction to the reaction from Gross, Hayman, and Levi [25]:

$3 / 2 \mathrm{PbF}_{2}(\mathrm{c})+\mathrm{Al}(\mathrm{c}) \rightarrow \mathrm{AlF}_{3}(\mathrm{c})+3 / 2 \mathrm{~Pb}(\mathrm{c}) ; \Delta H=$ $-118.53 \mathrm{kcal}$ from which we obtain:

$3 / 2 \mathrm{Be}(\mathrm{c})+\mathrm{AlF}_{3}(\mathrm{c}) \rightarrow \mathrm{Al}(\mathrm{c})+3 / 2 \mathrm{BeF}_{2}(\mathrm{c}) ; \Delta H=$ $-7.47 \mathrm{kcal}$ and using $\Delta H f^{\circ}\left[\mathrm{AlF}_{3}(\mathrm{c})\right]=-359.5 \mathrm{kcal}$ $\cdot \mathrm{mol}^{-1}[3], \quad \Delta H f^{\circ}\left[\mathrm{BeF}_{2}(\mathrm{c})\right]=-244.6 \quad \mathrm{kcal} \cdot \mathrm{mol}^{-1}$. However, a more recent direct determination of $\Delta H f^{\circ}\left[\mathrm{AlF}_{3}(\mathrm{c})\right]=-361.0 \mathrm{kcal} \cdot \mathrm{mol}^{-1}$ by Rudzitis et al. [26] would lead to $\Delta H f^{\circ}\left[\mathrm{BeF}_{2}(\mathrm{c})\right]=-245.6 \mathrm{kcal}$ $\cdot \mathrm{mol}^{-1}$.

\subsection{Other Data}

There is a path to $\Delta\left(\Delta H f^{\circ}\right)\left[\mathrm{BeO}(\mathrm{c})-\mathrm{BeF}_{2}(\mathrm{c})\right]$ and another to $\Delta H f^{\circ}\left[\mathrm{BeF}_{2}(\mathrm{c})\right]$ both of which involve $\mathrm{BeF}_{2}(\mathrm{~g})$ in high temperature gas phase equilibria. These can be referred to $\mathrm{BeF}_{2}$ (c) with the enthalpy of sublimation of $\mathrm{BeF}_{2}$. Table 5 summarizes the second

TABLE 5. Summary of values for $\Delta \mathrm{H}^{\circ}{ }_{\text {subl }}\left[\mathrm{BeF}_{2}(\mathrm{c})\right]$ at $298 \mathrm{~K}$

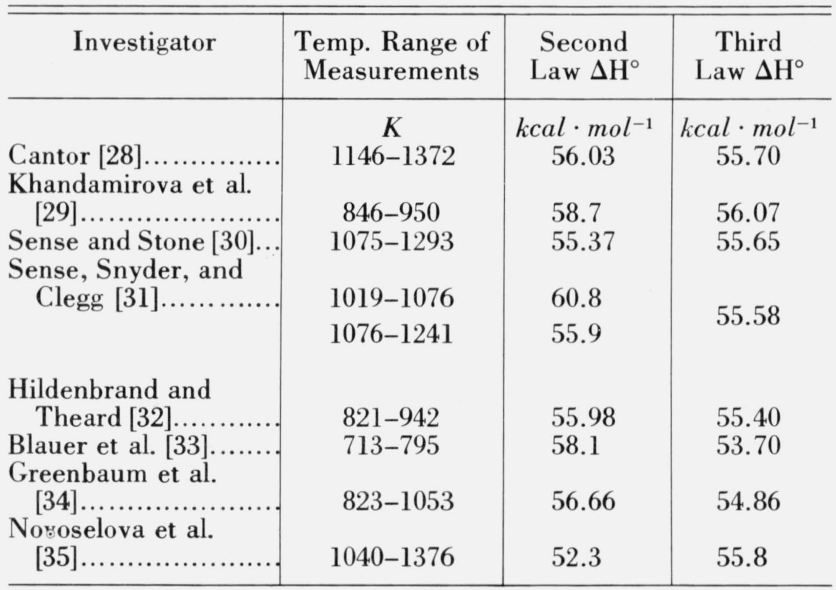


and third law $\Delta H_{\text {subl }}^{\circ} \mathrm{BeF}_{2}$ calculated from the vapor pressure measurements on the crystal and liquid. From these data we have chosen $\Delta H_{\text {subl }}^{\circ}=55.7 \mathrm{kcal}$ - $\mathrm{mol}^{-1}$. Because the thermal functions of $\mathrm{BeF}_{2}(\mathrm{~g})$ are based on an estimate for one of the three vibrational frequencies and the thermal functions of the condensed phases at high temperature are only approximate, we estimate an uncertainty of $\pm 2.0 \mathrm{kcal} \cdot \mathrm{mol}^{-1}$. The gas phase equilibria calculations are summarized in table 6 . Because of the many uncertainties inherent in these data, we have not assigned any weight to these measurements. The thermal functions used are given in [27]. ${ }^{4}$

TABLE 6. Gas phase equilibria involving $\mathrm{BeF}_{2}(\mathrm{~g})$

\begin{tabular}{|c|c|c|c|c|c|}
\hline \multirow[t]{2}{*}{ Reference } & \multirow[t]{2}{*}{ Reaction } & \multicolumn{2}{|c|}{$\begin{array}{c}\Delta\left(\Delta H f^{\circ}\right)[\mathrm{BeO}(\mathrm{c}) \\
\left.-\mathrm{BeF}_{2}(\mathrm{c})\right]\end{array}$} & \multicolumn{2}{|c|}{$\Delta H f^{\circ}\left[\mathrm{BeF}_{2}(\mathrm{c})\right]$} \\
\hline & & 2d Law & 3d Law & 2d Law & 3d Law \\
\hline$[36] \ldots \ldots \ldots$ & $\begin{array}{c}\mathrm{BeO}(\mathrm{c})+2 \mathrm{HF}(\mathrm{g}) \rightarrow \\
\mathrm{BeF}_{2}(\mathrm{~g})+\mathrm{H}_{2} \mathrm{O}(\mathrm{g})\end{array}$ & $\begin{array}{l}\text { kcal } \\
105\end{array}$ & $\begin{array}{r}m o l^{-1} \\
101\end{array}$ & kcal & $\mathrm{mol}^{-1}$ \\
\hline$[32] \ldots$ & $\begin{array}{c}\mathrm{BeF}_{2}(\mathrm{~g})+2 \mathrm{Al}(\mathrm{c}) \rightarrow \\
\mathrm{Be}(\mathrm{c})+2 \mathrm{AlF}(\mathrm{g})\end{array}$ & & & -242 & -238 \\
\hline
\end{tabular}

\subsection{The Selection of $\Delta H f^{\circ}\left[\mathrm{BeF}_{2}(\mathrm{c})\right]$ and $\Delta\left(\Delta H f^{\circ}\right)\left[B e O(c)-B e F_{2}(c)\right]$}

From the values for $\Delta H f^{\circ}\left[\mathrm{BeF}_{2}(\mathrm{c})\right]$ in 3.2 and 3.3 our "best" value for $\mathrm{BeF}_{2}(\mathrm{c}$, quartz) appears to be $-245.4 \mathrm{kcal} \cdot \mathrm{mol}^{-1}$. Tentatively, then our $\Delta\left(\Delta H f^{\circ}\right)$ $\left[\mathrm{BeO}(\mathrm{c})-\mathrm{BeF}_{2}(\mathrm{c})\right]=99.7 \mathrm{kcal} \cdot \mathrm{mol}^{-1}$.

As cited earlier the data from Kolesov et al. [9] yielded $\Delta(\Delta H f)\left[\mathrm{BeO}(\mathrm{c})-\mathrm{BeF}_{2}(\mathrm{aq})\right]=107.085 \mathrm{kcal} \cdot$ $\mathrm{mol}^{-1}$, where the $\mathrm{BeF}_{2}(\mathrm{aq})$ is in $340\left(\mathrm{HF}+3.826 \mathrm{H}_{2} \mathrm{O}\right)$. They also measured the enthalpy of solution of $\mathrm{BeF}_{2}(\mathrm{c}, \beta$-cristobalite $)$ to the same final solution, $\Delta H=-8.07 \mathrm{kcal} \cdot \mathrm{mol}^{-1}$. If we combine these results with our selected value for $\mathrm{BeO}(\mathrm{c}), \Delta H f^{\circ}=-145.7$ $\mathrm{kcal} \cdot \mathrm{mol}^{-1}$ we obtain for $\mathrm{BeF}_{2}(\mathrm{c}, \beta$-cristobalite $)-244.7$ $\mathrm{kcal} \cdot \mathrm{mol}^{-1}$. This indicates an enthalpy of transition of $0.7 \mathrm{kcal} \cdot \mathrm{mol}^{-1}$ between the two forms. Reported values for similar transitions in $\mathrm{SiO}_{2}$ [3], $\mathrm{CaF}_{2}$ [37], and $\mathrm{BeCl}_{2}$ [38] are $0.37,1.14$ and $1.32 \mathrm{kcal} \cdot \mathrm{mol}^{-1}$, respectively.

\section{Assigned Uncertainties}

We have tried to indicate some measure of the uncertainty in the reported values of $\Delta H$ and in the derived $\Delta H f^{\circ}$ 's by the number of significant figures given, following the convention that the overall uncertainty lies between 2 and 20 units of the last figure. The uncertainty in the $\Delta H f^{\circ}$ 's depends on the uncertainties of all the determinations in the total chain of reactions used to establish the value. But the values also are given so that the experimental data from which they are derived may be recovered with an accuracy

${ }^{4}$ Use of a more recent set of thermal functions [40], also based on an estimate, could change $\Delta H_{\text {subl }}^{\circ}$ of $\mathrm{BeF}_{2}$ by a few tenths of a kcal, well within the assigned uncertainty. equal to that of the original experimental quantities.

The overall uncertainties in the $\Delta H^{\prime}$ 's are based on many factors - the experimental technique used, the details given, the number of measurements, the standard deviation of the reported results, the magnitude and reliability of the corrections to $298.15 \mathrm{~K}$, and the reliability of previous work of the investigators. A strictly mathematical evaluation can therefore not be made. For this reason we shall consider only the discussion of the assignment of uncertainties to our "best" values for $\Delta H f^{\circ}[\mathrm{BeO}(\mathrm{c})]$ and $\Delta H f^{\circ}\left[\mathrm{BeF}_{2}(\mathrm{c})\right]$.

Kilday et al. reported the uncertainty in their measurements of $\Delta H$ of solution of $\mathrm{BeO}(\mathrm{c})$ in aqueous 24 percent $\mathrm{HF}$ to be $\pm 0.05 \mathrm{kcal} \cdot \mathrm{mol}^{-1}$. Kolesov et al. state their uncertainty to be $\pm 0.12 \mathrm{kcal} \cdot \mathrm{mol}^{-1}$. Bear and Turnbull state the uncertainties in their measurements to be $\pm 0.6, \pm 0.3, \pm 0.6$, and $\pm 0.9 \mathrm{kcal} \cdot \mathrm{mol}^{-1}$ for the solution of $\mathrm{Be}(\mathrm{c})$ in $12,22.6,30$, and 40 percent $\mathrm{HF}$ solutions, respectively. In calculating the $\Delta(\Delta H f)$ $\left[\mathrm{BeO}(\mathrm{c})-\mathrm{BeF}_{2}(\mathrm{aq})\right]$ and $\left.\Delta H f\left[\mathrm{BeF}_{2} \mathrm{aq}\right)\right]$ we ir roduced errors due to the uncertainties in our values for $\Delta H f^{\circ}$ $\mathrm{F}^{-}(\mathrm{aq})$ and $\varphi_{L} \mathrm{HF}$, but these errors essentially cancel in obtaining $\Delta H f^{\circ}[\mathrm{BeO}(\mathrm{c})]$. We introduce a \pm 0.05 $\mathrm{kcal} \cdot \mathrm{mol}^{-1}$ uncertainty by our correction of $\Delta H f$ $\left[\mathrm{BeF}_{2}(\mathrm{aq})\right]$ to $X=100$. This is negligible. The overall uncertainty obtained from the combined results of Bear and Turnbull and Kilday et al. is $\pm 0.6 \mathrm{kcal} \cdot \mathrm{mol}^{-1}$; similarly from the results of Kolesov et al. and Bear and Turnbull. The $\Delta H f^{\circ}[\mathrm{BeO}(\mathrm{c})]$ derived from the combination of the results of Kilday et al., and Churney and Armstrong, is dependent upon $\Delta H f^{\circ}\left[\mathrm{F}^{-}(\mathrm{aq})\right]$; hence the overall uncertainty must be $\pm 1.2 \mathrm{kcal} \cdot \mathrm{mol}^{-1}$.

The uncertainty in the Armstrong and Coyle measurement is $\pm 0.2 \mathrm{kcal} \cdot \mathrm{mol}^{-1}$. However, the final solution here is not dilute with respect to the $\mathrm{BeF}_{2}(\mathrm{aq})$. Even with the estimated mixing correction to the measured $\Delta H$, the uncertainty in the derived $\Delta H f^{\circ}$ $[\mathrm{BeO}(\mathrm{c})]$ must be $\pm 1.5 \mathrm{kcal} \cdot \mathrm{mol}^{-1}$. Similarly, although the uncertainty in the measurements of Thompson et al., on $\mathrm{Be}(\mathrm{c})$ in $\mathrm{HCl}$ is $\pm 0.1 \mathrm{kcal} \cdot \mathrm{mol}^{-1}$ (for $\mathrm{BeO}$ in $\mathrm{HCl}$ from Kilday et al. it is $\pm 0.5 \mathrm{kcal} \cdot \mathrm{mol}^{-1}$ ) the overall uncertainty in the derived $\Delta H f^{\circ}[\mathrm{BeO}(\mathrm{c})]$ is $+1.5 \mathrm{kcal} \cdot \mathrm{mol}^{-1}$. For our "best" value for $\Delta H f^{\circ}$ $[\mathrm{BeO}(\mathrm{c})]$ we assign an uncertainty of $\pm 0.6 \mathrm{kcal} \cdot \mathrm{mol}^{-1}$. Churney and Armstrong assigned $\pm 0.8 \mathrm{kcal} \cdot \mathrm{mol}^{-1}$ to their value for $\Delta H f^{\circ}\left[\mathrm{BeF}_{2}(\right.$ amorph $\left.)\right]$. The indirect determination from the measurements of Gross et al. have an overall uncertainty of $\pm 0.8 \mathrm{kcal} \cdot \mathrm{mol}^{-1}$. We assign an overall uncertainty of $\pm 0.8 \mathrm{kcal} \cdot \mathrm{mol}^{-1}$ to our "best" value for $\Delta H f^{\circ}\left[\mathrm{BeF}_{2}(\mathrm{c})\right]$.

\section{A Key Assumption}

The interpretation of the data and the values given are internally consistent with our value for $\Delta H f^{\circ}$ [HF(aq, std. state)] [3], and lend support to this value; eg., the values for $\Delta\left(\Delta H f^{\circ}\right)\left[\mathrm{BeO}(\mathrm{c})-\mathrm{BeF}_{2}\right.$ (quartz) $]$ from our 'selected' values, independent of $\mathrm{HF}(\mathrm{aq})$ are in excellent agreement with that derived from the Kolesov et al. difference, $\mathrm{HF}$ dependent, if one assumes a $\Delta H_{\text {trans }}$ of $0.7 \mathrm{kcal} \cdot \mathrm{mol}^{-1}$ for the $\beta$ cristobalite to the quartz form. Also the $\Delta H f\left[\mathrm{BeF}_{2}(\mathrm{aq}\right.$, in $\left.\mathrm{HF})\right]$ from the Bear and Turnbull measurements, dependent upon HF 
are in excellent agreement with that derived from the $\Delta H_{\text {soln }}$ (measured by Kilday and Churney) of a $\mathrm{BeF}_{2}$ (amorph) sample whose $\Delta H f^{\circ}$ was measured directly by Churney and Armstrong and is thus independent of $\Delta H f^{\circ}[\mathrm{HF}(\mathrm{aq})]$. However there is also evidence $[39,40,41]$ that the 'selected' value for HF may be too positive by 0.3 to $0.4 \mathrm{kcal} \cdot \mathrm{mol}^{-1}$. If so, this would involve a reinterpretation of the data.

In summary:

$\Delta H f^{\circ}[\mathrm{BeO}(\mathrm{c})]=-145.7 \pm 0.6 \mathrm{kcal} \cdot \mathrm{mol}^{-1}$

$$
\left(-609.6 \pm 2.5 \mathrm{~kJ} \cdot \mathrm{mol}^{-1}\right)
$$

$\Delta H f^{\circ}\left[\mathrm{BeF}_{2}(\mathrm{c}\right.$, quartz $\left.)\right]=-245.4 \pm 0.8 \mathrm{kcal} \cdot \mathrm{mol}^{-1}$

$$
\left(-1026.8 \pm 3.3 \mathrm{~kJ} \cdot \mathrm{mol}^{-1}\right) \text {. }
$$

\section{References}

[1] Kilday, M. V., Prosen, E. J., and Wagman, D. D., J. Res. Nat. Bur. Stand. (U.S.) 77A2 (Phys. and Chem.) No. 2, 217-225 (Mar--Apr. 1973).

[2] Churney, K. L., and Armstrong, G. T., J. Res. Nat. Bur. Stand. (U.S.) 73A, (Phys. and Chem.), No. 3, 281-297 (May-June 1969).

[3] Wagman, D. D., Evans, W. H., Parker, V. B., Halow, I., Bailey, S. M., and Schumm, R. H., Selected Values of Chemical Thermodynamic Properties, Nat. Bur. Stand. (U.S.), Tech. Note 270-3. 264 pp. (Jan. 1968); Parker, V. B., Wagman, D. D., Evans, W. H., Nat. Bur. Stand. (U.S.), Tech. Note 270-6, 106 pp. (Nov. 1971).

[4] Moose, J. E., and Parr, S. W., J. Am. Chem. Soc. 46, 2656 (1924).

[5] Roth, W. A., Börger, E., and Siemonsen, H., Z. anorg. u. allgem. Chem. 239, 321 (1938).

[6] Neumann, B., Kröger, C., and Kunz, H., Z. anorg. u. allgem. Chem. 218, 379 (1934).

[7] Mielenz, W., and v. Wartenberg, H., Z. anorg. u. allgem. Chem. 116, 267 (1921).

[8] Cosgrove, L. A., and Snyder, P. E., J. Am. Chem. Soc. 75, 3102 (1953).

[9] Neumann, B., Kröger, C., and Haebler, H., Z. anorg. u. allgem. Chem. 204, 81 (1932).

[10] Kolesov, V. P., Popov, M. M., and Skuratov, S. M., Zhur. Neorg. Khim. 4, 1233 (1959).

[11] Matignon, C., and Marchal, G., Compt. rend. 183, 927 (1926).

[12] Copaux, H., and Philips, C., Compt. rend. 176, 579 (1923).

[13] Bear, I. J., and Turnbull, A. G., J. Phys. Chem. 69, 2828 (1965).

[14] Armstrong, G. T., and Coyle, C. F., U.S. AEC AED-Conf-65358-1, 35 pp. (1965).

[15] Fricke, R., and Wüllhorst, B., Z. anorg. u. allgem. Chem. 205, 127 (1932).
[16] Parker, V. B., Nat. Stand. Ref. Data Ser., Nat. Bur. Stand. (U.S.), 2, 66 pp. (Apr. 1, 1965).

[17] Thompson, C. J., Sinke, G. C., and Stull, D. R., J. Chem. Eng. Data 7,380 (1962).

[18] Blachnik, R. O. G., Gross, P., and Hayman, C., Fulmer Research Inst. Scientific Rept. No. 5, Contract AF 61(052)-863 (July 1968).

[19] Smirnov, M. V., and Chukreev, N. Ya., Zhur. Neorg. Khim. 3, 2445 (1958).

[20] Matignon, C., and Marchal, G., Bull. soc. chim. France [4] 39, 167 (1926).

[21] Matignon, C., and Marchal, G., Compt. rend. 181, 859 (1925).

[22] Fricke, R., and Severin, H., Z. anorg. u. allgem. Chem. 205, 287 (1932).

[23] Taylor, A. R., and Gardner, T. E., U. S. Bur. of Mines Rept. Invest. 6664, 15 pp. (1965).

[24] Gross, P., Hayman, C., and Bingham, J. T., Fulmer Research Inst. Ltd. Sci. Rept. No. 7, Contract AF 61(052)-447, 10 pp. (Feb. 1971).

[25] Gross, P., Hayman, C., and Levi, D. L., Met. Soc. Conf. 8, 903 (1961).

[26] Rudzitis, E., Feder, H. M., and Hubbard, W. N., J. Inorg. Chem. 6, $1716(1967)$

[27] Dow Chemical Company, JANAF Thermochemical Tables PB 168370 (Clearinghouse for Federal Scientific and Technical Information, Springfield, Virginia, August 1965).

[28] Cantor, S., J. Chem. Eng. Data 10, 237 (1965).

[29] Khandamirova, N. E., Evseev, A. M., Pozharskaya, G., et al., Zhur. Neorg. Khim. 4, 2192 (1959).

[30] Sense, K. A., and Stone, R. W., J. Phys. Chem. 62, 453 (1958).

[31] Sense, K. A., Snyder, M. J., and Clegg, J. W., J. Phys. Chem. $\mathbf{5 8}, 223$ (1954).

[32] Hildenbrand, D. L., and Theard, L. P., J. Chem. Phys. 42, 3230 (1965).

[33] Blauer, J. A., Greenbaum, M. A., and Farber, M., J. Phys. Chem. 69, 1069 (1965).

[34] Greenbaum, M. A., Foster, J., Arin, M. L., and Farber, M., J. Phys. Chem. 67, 36 (1963).

[35] Novoselova, A. V., Muratov, F. Sh., Reshetnikova, L. P., and Gordeev, I. V., Vestnik Moskov, Univ., Ser. Mat., Mekh., Astron., Fiz. i Khim, No. 6, 181 (1958).

[36] Greenbaum, M. A., Arin, M. L., and Farber, M., J. Phys. Chem. 67, 1191 (1963).

[37] Naylor, B. F., J. Am. Chem. Soc. 67, 150 (1945).

[38] McDonald, R. A., and Oetting, F. L., J. Phys. Chem. 69, 3839 (1965).

[39] Armstrong, G. T., Hydrogen Fluoride and the Thermochemistry of Fluorine, Nat. Bur. Stand. (U.S.), Tech. Note. 513, 32 pp. (Oct. 1970).

[40] Stull, D. R., and Prophet, H., Eds. JANAF Thermochemical Tables, 2nd ed., Nat. Stand. Ref. Data Ser., Nat. Bur. Stand. (U.S.), 37 (1971).

[41] Domalski, E. S., and Armstrong, G. T., J. Res. Nat. Bur. Stand. (U.S.) 71A, (Phys. and Chem.) No. 3, 195-202 (1967).

(Paper 77A2-765) 